\title{
Molecular characterization of bacteria isolated from the Kingdom of Saudi Arabia and their uses against pathogenic fungi causing dermatological diseases
}

\author{
El-Hamshary, O. I. M. ${ }^{1,2 \star}$, Huda Mohammed Ahmed Sheikh ${ }^{3}$ and Khattab, A. A. ${ }^{4}$ \\ ${ }^{1}$ Department of Biology, Faculty of Science, King Abdulaziz University, Jeddah, Saudi Arabia. \\ ${ }^{2}$ Department of Microbial Genetics National Research Centre, Cairo, Egypt. \\ ${ }^{3}$ Department of Microbiology, Faculty of Science (Girls), King Abdulaziz University. Jeddah, Saudi Arabia. \\ ${ }^{4}$ Department of Genetics and Cytology, National Research Centre, Dokki, Cairo, Egypt.
}

Accepted 16 October, 2012

\begin{abstract}
Random amplified polymorphic DNA (RAPD) assay and antimicrobial activities were used for the detection of genetic variations of antimicrobial isolates from the Kingdom Saudi of Arabia. Soil samples were collected from El-Madina El-Monawara, El-Taif, El-Jouf and El-Dammam for bacterial isolation. Bacterial isolates were evaluated for their antimicrobial activities against pathogenic fungi which cause dermatological diseases; Acremonium sp., Microsporium gypseum, Microsporium gallinae, Exserohilum sp., Trichphyton sp. and Aspergillus niger. Results indicate that all the bacterial isolates showed different levels of antagonistic activities against the pathogenic fungi. Esherichia coli M2, Bacillus megaterium M3 and Bacillus subtilis M10 showed strong effect against all the tested pathogenic fungi. $B$. subtilis $\mathrm{J} 1$ isolate showed strong effect against the two pathogenic fungi $M$. gallinae and Exserohilum sp. Nine strains were tested for their antibiotic response. The results show that different antibiotic response was found. RAPD fingerprinting technique was applied to study the genetic diversity among the tested strains. Results indicate that there was a significant genomic diversity among the $B$. subtilis strains and this diversity was highly correlated with habitats and the antagonistic effect of the studied strains.
\end{abstract}

Key words: Random amplified polymorphic DNA-polymerase chain reaction (RAPD-PCR), bacterial isolates, pathogenic fungi, Kingdom of Saudi Arabia.

\section{INTRODUCTION}

The dermatological pathogenic microbes could penetrate the skin through the cracks ulcers causing skin infections. Their treatment depends on different antibiotics, which have several side effects. Bacterial species producing antibiotics have been used as bio-control agents against pathogenic fungi (Yilmaz et al., 2005; Gebreel et al., 2008). Certain bacterial and fungal isolates were isolated from soil samples collected from El-Madina El-Monawara, and showed significant antagonistic effect against

\footnotetext{
*Corresponding author. E-mail: olaelhamshary@hotmail.com.
}

pathogenic microbes causing dermatological diseases (Sheikh, 2010).

Molecular techniques based on genomic DNA have extensively been used for analysis of genetic diversity. When the reproducibility can be stably rendered with replications by the same primers, random amplified polymorphic DNAs (RAPDs) technique is very useful since it is fast, cheap and an easy method in genetic mapping and characterization. One prominent advantage of the RAPD is that it can easily be applied and employed on antagonistic gram (-) and gram (+) bacteria (Cirvilleri et al., 2005; Baysal et al., 2008).

This study is an attempt to investigate the antimicrobial activity of certain microorganisms isolated from the soil 
collected from different areas in the Kingdom of Saudi Arabia (El-Madina El-Monawara, El-Taif, El-Jouf and ElDammam) against some pathogenic microorganisms which cause wounds inflammation and ulcers such as Acremonium sp., Microsporium gypseum, Microsporium gallinae, Exserohilum sp., Trichphyton sp. and Aspergillus niger. Also, RAPD method was used to investigate the genetic heterogeneity of Bacillus and Esherichia coli strains isolated from different habitats in relation to their antimicrobial activity against pathogenic fungi causing dermatological diseases.

\section{MATERIALS AND METHODS}

\section{Microbial strains, media and culture conditions}

Bacterial isolates from soil samples were collected from different localities (El-Madina El-Monawara, El-Taif, El-Jouf and ElDammam, Kingdom of Saudi Arabia). The pathogenic fungi isolates were obtained from King Fahd-hospital, Jeddah city. The blood agar culture medium recommended by Madigan and Martinko (2005) was used for cultivation of pathogenic bacteria isolates. Sabouraud dextrose agar medium was used for fungal growth (Georg et al., 1954). The bacterial isolates were identified according to Bergey's manual of systematic bacteriology (Krieg and Holt, 1984; Sneath et al., 1986).

\section{Antagonism test}

The antagonistic effects of the bacterial species were tested according to the method of Umechuruba and Nwachukwa (1997).

\section{Testing of antibiotic response}

The antimicrobial resistance patterns of bacterial strains were routinely tested by the single-disk diffusion method using MullerHinton agar against the following antibiotics: Ampicilln (Amp, 25 $\mu \mathrm{g} / \mathrm{ml})$, streptomycin $(\mathrm{Sm}, 10 \mu \mathrm{g} / \mathrm{ml})$, tetracycline $(\mathrm{Tc}, 30 \mu \mathrm{g} / \mathrm{ml})$ and norfloxacine (Nor, $10 \mu \mathrm{g} / \mathrm{ml})$, gentamycin $(\mathrm{Gm}, 10 \mu \mathrm{g})$. Zone sizes were interpreted by using standard recommendations.

\section{Isolation of total DNA from isolated strains}

Total DNA was isolated according to Sambrook et al. (1989). The quantity and purity of the obtained DNA were determined according to the ultraviolet (UV)-absorbance at 260 and $280 \mathrm{~nm}$ using spectrophotometer (Shimadzu UV-VIS model UV-240).

\section{RAPD analysis of new bacterial isolates}

Polymerase chain reaction (PCR)-GOLD Master-Mix Beads (BIORON, Germany, Cat. No. 10020-96) were used for PCR technique. Each bead contains all of the necessary reagents, except primer and DNA template, for performing $25 \mu \mathrm{l}$ PCR amplification reactions. Two different primers were used in the present study. The first primer (No.1) sequence was 5'-GTC CAC ACG G-3'. The second primer (No.2) sequence was 5'-GGT CCC TGA C-3'. All primers were supplied by Operon Technologies Company, Netherlands. To each ready-to-go PCR bead, $12 \mathrm{ng}$ of the used random primer and $40 \mathrm{ng}$ of the purified DNA sample were added. The total volume of the amplification reaction was completed to $25 \mu \mathrm{l}$ using sterile distilled water. The amplification protocol was carried out as follows: denaturation at $95^{\circ} \mathrm{C}$ for $5 \mathrm{~min}$. 35 cycles each consists of the following steps: denaturation at $95^{\circ} \mathrm{C}$ for $1 \mathrm{~min}$; primer annealing at $32^{\circ} \mathrm{C}$ for $2 \mathrm{~min}$ according to guaninecytosine (GC) ratio of each primer and incubation at $72^{\circ} \mathrm{C}$ for $2 \mathrm{~min}$, for DNA polymerization. At the end, the PCR was held at $4^{\circ} \mathrm{C}$ till analysis. The amplified DNA products from RAPD analysis were electrophorated in 1\% agarose gel and $1 \times$ TBE buffer at consistent 100 volt for about $2 \mathrm{~h}$. The different band sizes were determined against $100 \mathrm{bp}$ ladder and the separated bands were stained with $0.5 \mu \mathrm{g} / \mathrm{ml}$ ethidium bromide and photographed using both Polaroid Instant Camera and UV Transilluminator.

\section{RESULTS AND DISCUSSION}

\section{Antagonism of isolated strains against dermatological fungi}

Nine bacterial strains were isolated from the soil samples collected from different localities from El-Madina AlMonwara (M2, M3 and M10), El-Taif (T2 and T3), El-Jouf (J1 and J3) and El-Dammam (D2 and D4), Kingdom of Saudi Arabia.

The bacterial strains were screened for their antifungal activity against some pathogenic microorganisms that cause wounds inflammation and ulcers, Acremonium sp., M. gypseum, M. gallinae, Exserohilum sp., Trichphyton sp. and $A$. niger. Experimental results show that all bacterial isolates had different levels of antagonistic activities against the pathogenic fungi (Table 1). E. coli M2, Bacillus megaterium M3 and Bacillus subtilis M10 showed the strongest effects against all tested pathogenic fungi. E. coli M2 showed effective biocontrol potential against all the tested fungi, that is, Trichphyton sp., M. gallinae, M. gypseum, Exserohilum sp., Acremonium sp., A. niger, with the inhibition zones 45, $72,85,85,75$ and15 mm, respectively. For $B$. megaterium $\mathrm{M} 3$, the inhibition zones were $70,69,60,75$, 85 and $25 \mathrm{~mm}$, respectively. On the other hand, inhibition zones were $65,85,67,65,60$ and $24 \mathrm{~mm}$, respectively, with $B$. subtilis $\mathrm{M} 10$. B. subtilis $\mathrm{J} 1$ and $\mathrm{J} 3$ produced inhibition zones of $60,85,40,75,12$ and $20 \mathrm{~mm}$, respectively and $50,22,40,35,70$ and $20 \mathrm{~mm}$. B. subtilis J1 showed strong effect against two pathogenic fungi, that is, M. gallinae and Exserohilum sp. B. subtilis D2 and $B$. subtilis D4, produced moderate inhibition zones, whereas, $B$. subtilis T2 and $B$. subtilis T3 could not produce clear antimicrobial activity against the tested pathogenic fungus.

As appeared from the obtained data, Bacillus was the dominant genus; these results were supported by several studies which indicated the efficient antimicrobial activity of soil bacteria especially the bacilli. In this connection, Aunpad and Na-Bangchang (2007) concluded that Bacillus pumilus isolated from the soil of Thailand produced new antimicrobial peptide with broad spectrum antibacterial activity including methicillin-resistant 
Table 1. The antagonistic effects of bacterial suspensions isolated from soil against pathogenic fungi expressed by inhibition zones $(\mathrm{mm})$.

\begin{tabular}{llcccccc}
\hline Bacterial isolate & Region & Trichphyton & M. gallinae & M. gypseum & Exserohilum & Acremonium & A. niger \\
\hline E. coli M2 & El-Madina & 45 & 72 & 85 & 85 & 75 & 15 \\
B. megaterium M3 & El-Madina & 70 & 69 & 60 & 75 & 85 & 25 \\
B. subtilis M10 & El-Madina & 65 & 85 & 67 & 65 & 60 & 24 \\
B. subtilis T2 & El-Taif & 20 & 0.0 & 0.0 & 45 & 0.0 & 0.0 \\
B. subtilis T3 & El-Taif & 0.0 & 0.0 & 0.0 & 0.0 & 0.0 & 12 \\
B. subtilis J1 & El-Jouf & 60 & 85 & 40 & 75 & 12 & 20 \\
B. subtilis J3 & El-Jouf & 50 & 22 & 40 & 35 & 70 & 20 \\
B. subtilis D2 & El-Dammam & 30 & 50 & 0.0 & 50 & 12 & 15 \\
B. subtilis D4 & El-Dammam & 25 & 57 & 45 & 50 & 30 & 0.0 \\
\hline
\end{tabular}

Table 2. Effect of different antibiotics on the growth of E. coli and Bacillus isolates.

\begin{tabular}{lccccc}
\hline Strain code & Sm 10 & Tc 30 & Nor 10 & Amp 25 & Gm 10 \\
\hline E. coli M2 & $\mathrm{S}$ & $\mathrm{S}$ & $\mathrm{R}$ & $\mathrm{R}$ & $\mathrm{S}$ \\
B. megaterium M3 & $\mathrm{S}$ & $\mathrm{R}$ & $\mathrm{R}$ & $\mathrm{R}$ & $\mathrm{S}$ \\
B. subtilis M10 & $\mathrm{S}$ & $\mathrm{R}$ & $\mathrm{S}$ & $\mathrm{R}$ & $\mathrm{S}$ \\
B. subtilis J & $\mathrm{S}$ & $\mathrm{S}$ & $\mathrm{S}$ & $\mathrm{S}$ & $\mathrm{S}$ \\
B. subtilis T2 & $\mathrm{S}$ & $\mathrm{R}$ & $\mathrm{S}$ & $\mathrm{R}$ & $\mathrm{S}$ \\
B. subtilis T3 & $\mathrm{S}$ & $\mathrm{R}$ & $\mathrm{R}$ & $\mathrm{S}$ & $\mathrm{S}$ \\
B. subtilis D4 & $\mathrm{S}$ & $\mathrm{R}$ & $\mathrm{S}$ & $\mathrm{R}$ & $\mathrm{S}$ \\
B. subtilis D2 & $\mathrm{S}$ & $\mathrm{S}$ & $\mathrm{S}$ & $\mathrm{S}$ & $\mathrm{S}$ \\
B. subtilis M3D3 & $\mathrm{S}$ & $\mathrm{S}$ & $\mathrm{S}$ & $\mathrm{S}$ & $\mathrm{S}$ \\
\hline
\end{tabular}

$\mathrm{S}$, Sensitive; R, resistant; Sm, streptomycin $10 \mu \mathrm{g}$; Tc, tetracycline $30 \mu \mathrm{g}$; Nor,: norfloxacine $10 \mu \mathrm{g}$; Amp, ampicillin $25 \mu \mathrm{g}$; Gm, gentamycin $10 \mu \mathrm{g}$.

Staphylococcus aureus (MRSA). E. coli M2 effectively suppressed colony growth of all tested fungal species. Yadav et al. $(2010,2007)$ reported that cytosolic proteins of $E$. coli are responsible for antifungal potential against pathogenic strains of Aspergillus fumigatus, Aspergillus flavus, A. niger and Candida albicans. Also, Mushtaq et al. (2010) reported that $E$. coli showed almost complete inhibition against pathogenic fungi such as $A$. niger and A. flavus.

\section{Antibiotics response of Bacillus and Escherichia coli isolates}

Five antibiotics were used to test all Bacillus and E. coli strains for their antibiotic response. Data are shown in Table 2. The results show that all isolates were sensitive to $\mathrm{Gm}$ and $\mathrm{Sm}$. At the same time, B. subtilis (M3D3), $B$. subtilis (J3) and $B$. subtilis (D2) were sensitive to the five antibiotics, and $B$. megaterium (M3) was resistance to Nor, Tc and Amp. The nine isolates were genetically different in their patterns of antibiotic resistance except $B$. subtilis (M10) which resembled $B$. subtilis (T2) and $B$. subtilis (D4) resistance pattern. E. coli (M2) was resistance to Amp and Nor, and $B$. subtilis (T3) was resistance to Tc and Nor. The susceptibility of bacilli to different antibiotics has been studied previously, and it has been demonstrated that, in principle, it should be possible to identify species on the basis of the results of susceptibility tests (Burke and McDonald, 1983; Castro et al., 1991). A large number of Bacillus strains assigned to different species were tested to determine their susceptibilities to antibiotics. Considerable interspecific differences in susceptibility were observed with chloramphenicol, Amp, and Tc (Reva et al., 1995).

\section{Molecular characterization of the bacterial isolates by PCR}

Studying genetic diversity of natural bacterial isolates as a new biocontrol agents became a global programs to determine genetic variation among strains populations. Two primers were selected to be used in this study. In order to score fingerprints, one band has assumed to be corresponded to one locus. A total of 148 allelic bands 


\section{$\begin{array}{llllllllllll}1 & 2 & 3 & 4 & 5 & 6 & 7 & 8 & 9 & 10 & 11\end{array}$}

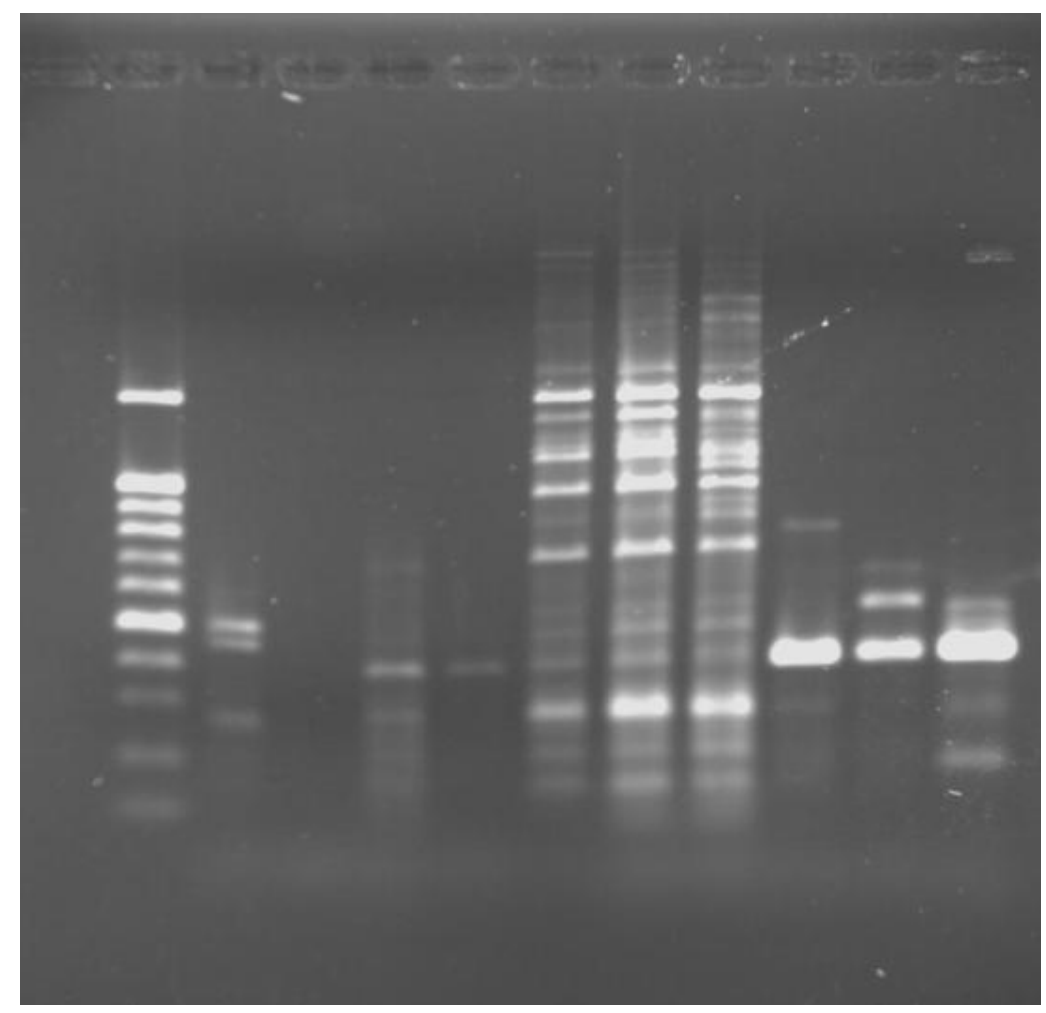

Figure 1. Photograph of DNA amplified banding patterns based on RAPD for ten different strains: E. coli $\mathrm{M} 2, B$. megaterium $\mathrm{M} 3, B$. subtilis $\mathrm{J} 3$, B. subtilis $\mathrm{T} 2$, $B$. subtilis D4, B. subtilis D2, B. subtilis M3D3, B. subtilis T3, E. coli pUC19 and B. subtilis M10 (lanes 2, 3, 4, 5, 6, 8, 9, 10 and 11) against 100 bp ladder DNA marker which has three distinct bands: 500, 1000, 2000 bp (lane 1) using primer No.1.

ranging between 100 and $\sim 3000$ bp were amplified as shown in Figures 1 and 2 for primers 1 and 2, respectively. No band out of 148 bands was monomorphic in all strains. The RAPD profiles of the ten strains were compared, and variation in the band profiles was observed for each primer; each strain has specific bands which were absent in others. The highest number which corresponded to 21 loci was found in $B$. subtilis M3D3, with primer No. 1, which ranged from 100 bp to $\sim 3000 \mathrm{bp}$. The lowest number which corresponded to 1 locus was found in $B$. subtilis T2, with primer No. 1, which was $400 \mathrm{bp}$ band. Analysis of the nine isolates by using two RAPD primers revealed that a total of 148 bands were scored (Table 3 ). B. subtilis D4 and B. subtilis D2 isolates were closest to $B$. subtilis M3D3, which possessed moderate antifungal activity; was found to be very diverse from $B$. subtilis M10 which had the most efficient antifungal activity. This diversity is highly correlated with habitats and the antagonistic effect of the studied strains.

DNA markers indicate the differences in the sequences of nucleic acid at a particular location or locations in the genome. In addition, they are independent of external factors, and the rates of polymorphism in these variable regions are high (Parmaksiz, 2004). One of the DNA marker techniques, RAPD, is based on the amplification of unknown DNA sequences and uses a single short and random oligonucleotide primer (Williams et al., 1990). This technique, which is fast and inexpensive, can detect DNA variations even at a single-base level. Hence, it has become a commonly used technique for exploring intraspecies and interspecies diversity (Roy et al., 1992; Carlson et al., 2001; Bardakc, 2001; Arslan and Tamkoc, 2011).

It was reported that high metabolic activities of Bacillus strains often correspond to their specific genotypes (Pinchuk et al., 2002). This genetic heterogeneity is interesting in view of the production of antimicrobial 


\section{$\begin{array}{lllllllllll}1 & 2 & 3 & 4 & 5 & 6 & 7 & 8 & 9 & 10 & 11\end{array}$}

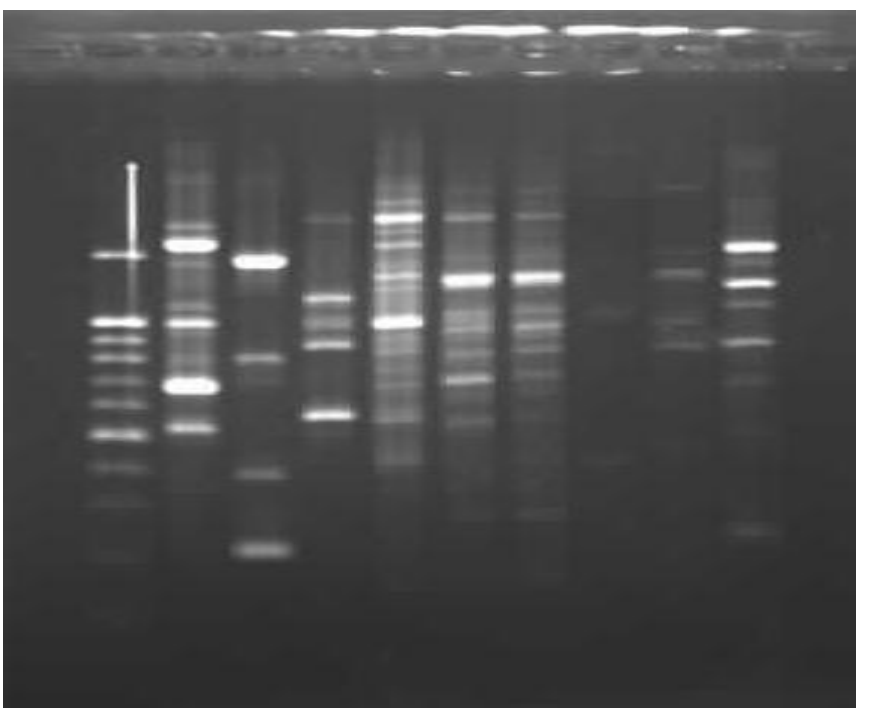

Figure 2. Photograph of DNA amplified banding patterns based on RAPD for ten different strains: E. coli M2, B. megaterium M3, $B$. subtilis $\mathrm{J} 3, B$. subtilis $\mathrm{T} 2, B$. subtilis $\mathrm{D} 4, B$. subtilis $\mathrm{D} 2, B$. subtilis M3D3, B. subtilis T3, E. coli pUC19 and $B$. subtilis M10 (lanes, 2, 3, 4, 5, 6, 8, 9, 10, and 11) against 100 bp ladder DNA marker which has three distinct bands: 500, 1000, 2000 bp (lane

1) using primer No.2.

Table 3. Number of DNA polymorphic bands in ten bacteria isolates amplified with two oligonucleotide primers.

\begin{tabular}{llc}
\hline Primer number & Bacteria isolate & $\begin{array}{c}\text { Number of fragments scored } \\
\text { of polymorphic loci }\end{array}$ \\
\hline E. coli M2 & 3 \\
B. megaterium M3 & 0 \\
B. subtilis J3 & 5 \\
B. subtilis T2 & 1 \\
B. subtilis D4 & 18 \\
B. subtilis D2 & 19 \\
B. subtilis M3D3 & 21 \\
B. subtilis T3 & 3 \\
E. coli pUC19 & 3 \\
B. subtilis M10 & 5 \\
& E. coli M2 & 8 \\
B. megaterium M3 & 6 \\
B. subtilis J3 & 5 \\
B. subtilis T2 & 13 \\
B. subtilis D4 & 10 \\
B. subtilis D2 & 10 \\
B. subtilis M3D3 & 4 \\
B. subtilis T3 & 6 \\
E. coli pUC19 & 8 \\
B. subtilis M10 & 0 \\
\hline
\end{tabular}


activity. Use of the RAPD method has extensive application for rapid typing of microorganisms at the species and subspecies levels (Stephan et al., 1994; Ronimus et al., 1997; Pinchuk et al., 2002). Due to the diversity of the environmental condition, the species or different strains of the same species such as $E$. coli did not show the same sort of phylogenic relationship among each other. Most of these different E. coli RAPD types were not geographically restricted. There was, as expected, a tendency of higher genetic relationship among E. coli strains isolated from the same locality, which was finally obtained, while some other strains differed from each other due to the environmental impact (Satyajit, 2009).

\section{REFERENCES}

Arslan E, Tamkoc A (2011). The application of ISSR-PCR to determine the genetic relationship and genetic diversity between narrow leaved bluegrass (Poa angustifolia) and rough bluegrass (Poa trivialis) accessions. Turk. J. Biol. 35:415-423.

Aunpad R, Na-Bangchang K (2007). A novel antimicrobial peptide With anti RSA activity. $17^{\text {th }}$ European Congress of Clinical Microbiology and Infectious Disease ICC, Munich, Germany.

Bardakc F (2001). Random amplified polymorphic DNA (RAPD) markers. Turk. J. Biol. 25:185-196.

Baysal Ö, Çaliskan M, Yeslova Ö (2008). An inhibitory effect of a new Bacillus subtilis strain (EU07) against Fusarium oxysporumf. sp. radicislycopersici. Physiol. Mol. Plant Pathol. 73:25-32.

Burke WFJ, McDonald KO (1983). Naturally occurring antibiotic resistance in Bacillus sphaericus and Bacillus licheniformis. Curr. Microbiol. 9:69-72.

Carlson JE, Tulsieram L.K, Glaubitz JC (2001). Segregation of random amplified DNA markers in F1 progeny of conifers. Theor. Appl. Genet. 83:194-200.

Castro GR, Ferrero MA, Mendez BS, Sineriz F (1991). A system for the differentiation of some closely related Bacillus species. J. Biotechnol. 20:105-108

Cirvilleri G, Spina S, Scuderi G, Gentile A, Cataral A (2005). Characterization of antagonistic root-associated Fluorescent Pseudomonas of transgenic and non-transgenic citrange troyer plants. J. Plant Pathol. 87(3):179-186.

Gebreel HM, E1-Mehalawy AA, E1-Kholy IM, Rifaat HM, Humid AA (2008). Antimicrobial Activities of Certain Bacteria Isolated from Egyptian Soil Against Pathogenic Fungi. J. Agric. Biol. Sci. 44:331339.

Georg LK, Ajello L, Papageorge C (1954). Use of cycloheximide in the selective isolation of fungi pathogenic to man. J. Lab. Clin. Med. 44 :422-428.

Krieg NR, Holt JG (1984). Bergey's manual of systematic bacteriology. Williams \& Wilkins, Baltimore and London.
Madigan M, Martinko J (2005). Brock Biology of Microorganisms (11th ed. ed.). Prentice Hall.

Mushtaq S, Ali A, Khokhar I, Mukhtar I (2010). Antagonisitic Potential of Soil Bacteria Against Food Borne Fungi. World Appl. Sci. J. 11(8):966-969.

Parmaksız I (2004). Analysis of Genetic Variation among Turkish Oxytona Section Species of Papaver Genus Using RAPD Markers, $\mathrm{PhD}$, Ankara University Institute of Natural and Applied Sciences.

Pinchuk IV, Bressolier P, Sorokulova IB, Verneuil B, Urdaci MC (2002). Amicoumacin antibiotic production and genetic diversity of Bacillus subtilis strains isolated from different habitats. Res. Microbiol. 153:269-276.

Reva ONV, Vyunitskaya A, Reznik SR, Kozachko IA, Smirnov VV (1995). Antibiotic Susceptibility as a taxonomic characteristic of the genus Bacillus. Int. J. Syst. Bacteriol. pp. 409-411.

Ronimus RS, Parker LE, Morgan HW (1997). The utilization of RAPDPCR for identifying thermophilic and mesophilic Bacillus species. FEMS Microbiol. Lett. 147:75-79.

Roy A, Frascaria N, MacKay J (1992). Segregating random amplified polymorphic DNAs (RAPDs) in Betula alleghaniensis. Theor. Appl. Genet. 85:173-180.

Sambrook J, Fritsch EF, Maniatis T (1989). Molecular Cloning; A Laboratory Manual, Second Edition Cold Spring Harbor.

Satyajit K (2009). A Simplified Analysis of Different Escherichia coli Strains by Using RAPD Technique. Not. Bot. Hort. Agrobot. Cluj. 37(2):257-260.

Sheikh HM ( 2010). Antimicrobial Activity of Certain Bacteria and Fungi Isolated from Soil Mixed with human Saliva against Pathogenic microbes causing Dermatological diseases. Saudi J. Biol. Sci. 17:331-339.

Sneath PH , Mair NS, Sharp E (1986). Bergey's Manual of Systematic Bacteriology Williams \& Wilkins, Baltimore and London.

Stephan R, Schraft H, Untermann F (1994). Characterization of Bacillus licheniformis with the RAPD technique (randomly amplified polymorphic DNA). Lett. Appl. Microbiol. 18:260-263.

Umechuruba Cl, Nwachukwa EO (1997). The effect of filtrates of seed borne fungi of African yam bean on seed germination and seedling development. Glob. J. Pure Appl. Sci. 3:165-176.

Williams JGK, Kubelik AR, LivakK J (1990). DNA polymorphisms amplified by arbitrary primers are useful as genetic markers. Nucleic Acids Res. 18:6531-6535.

Yadav V, Mandhan R, Kumar M, Gupta J, Sharma GL (2010). Characterization of the Escherichia coli antifungal protein PPEBL21, Int. J. Microbiol. 196363-1963637.

Yadav V, Mandhan, R, Pasha Q, Pasha S, Katyal A, Chhillar A, Gupta K J, Dabur R, Sharma GL (2007). An antifungal protein from Escherichia coli. J. Med. Microbiol. 56:637-644.

Yilmaz M, Soran H, Beyatli Y (2005). Antimicrobial activities of some Bacillus spp. Strain isolated from the soil. Microbiology 161:127-131. 